\title{
Rekonstruksi Citra Pada Super Resolusi Menggunakan Interpolasi Bicubic
}

\author{
Bagus Hardiansyah ${ }^{1}$, Aidil Primasetya Armin ${ }^{2}$, Anton Breva Yunanda ${ }^{3}$ \\ ${ }^{1}$ Jurusan Teknik, Fakultas Teknik Informatika, Universitas 17 Agustus 1945 Surabaya \\ ${ }^{2} J u r u s a n$ Teknik, Fakultas Teknik Informatika, Universitas 17 Agustus 1945 Surabaya \\ ${ }^{3}$ Jurusan Teknik, Fakultas Teknik Informatika, Universitas 17 Agustus 1945 Surabaya \\ Email: 'bagushardiansyah@untag-sby.ac.id, ${ }^{2}$ aidilprimasetya@untag-sby.ac.id, ${ }^{3}$ antonbreva@untag-sby.ac.id
}

\begin{abstract}
Digital image interpolation is important role in the geometric manipulation of a digital image. Interpolation is related to the process of mapping pixels, forward and reverse.

Then this research will implementation of the bicubic interpolation method in the image process that is 16 pixel $4 \times 4$ nearest neighborhood contained in the input image and generated a new pixel value with upscale $3 x$ and $4 x$. Tests carried out on the type of $R G B$ and images with BMP format with a variety of different image sizes. Tests with secondary data "Set5" and "Set14" validation results on upscale $3 x$ using the PSNR method and results based on the average value of the secondary data "Set5" 30.40 and "Set14" 27.54
\end{abstract}

Keywords: Bicubic Interpolation, Super Resolution, PSNR,

Abstrak. Interpolasi citra digital memegang peranan penting dalam manipulasi geometris dari sebuah citra digital. Interpolasi berkaitan erat dengan proses pemetaan piksel-piksel baik secara forward maupun reverse.

penelitian ini akan dibahas implementasi metode interpolasi bicubic pada proses citra yang dilakukan dengan 16 nilai piksel pada $4 \times 4$ ketetanggaan terdekat yang terdapat pada citra input dan dihasilkan nilai piksel baru dengan upscale $3 \times$ dan $4 x$. Pengujian di lakukan pada jenis citra RGB dan citra image dengan format BMP dengan berbagai ukuran citra yang berbeda-beda. Dilakukan pengujian dengan data sekunder "Set5" dan "Set14" hasil validasi pada upscale $3 x$ menggunakan metode PSNR dan hasil berdasarkan nilai rata-rata dari data sekunder tersebut "Set5" $\mathbf{3 0 . 4 0}$ dan "Set14" 27.54

Kata Kunci: Interpolasi Bicubic, PSNR, Forward, Reserve.

\section{Pendahuluan}

Seiring berjalannya waktu kebutuhan manusia akan teknologi informasi semakin meningkat. Teknologi informasi yang masih perkembang pada saat ini adalah teknologi pengolahan citra seperti kamera, salah satu kemajuannya adalah peningkatan resolusi untuk mendapat citra resolusi tinggi baik untuk pengambilan gambar maupun video. Ada beberapa cara untuk mendapatkan citra dengan resolusi tinggi, salah satunya yaitu dengan meningkatkan kualitas sensor ataupun lensa. Meskipun teknik ini dapat meningkatkan resolusi citra, namun cara tersebut membutuhkan biaya yang besar dan belum dapat memenuhi kebutuhan citra resolusi tinggi di beberapa bidang(Yudhi, 2010)

Cara lain untuk mendapatkan resolusi citra yang tinggi dengan menggunakan pengolahan citra digital, berbagai penelitian untuk memperoleh citra resolusi tinggi dengan pendekatan yang lain, pendekatan tersebut berupa perangkat lunak yang salah satunya dibangun dengan teknik Super Resolusi.

Super Resolusi digunakan untuk perbaikan citra yang dapat mengubah citra beresolusi rendah tersebut menjadi sebuah citra beresolusi tinggi. Dengan demikian, biaya untuk mendapatkan citra dengan resolusi tinggi dapat lebih murah (Imaddudin, 2011). Terdapat 2 output yang di hasilkan oleh teknik Super Resolusi yaitu berupa gambar resolusi tunggal disebut teknik Super Resolusi statis dan gambar rangkaian maka disebut teknik Super Resolusi Dinamis (Wayan, 2011).

Terdapat banyak metode interpolasi yang sering digunakan untuk melakukan memperbesar resolusi citra, salah satunya adalah Interpolasi Nearest Neighbor, Interpolasi Bilinear, dan Interpolasi Bicubic. Interpolasi Nearest Neighbor merupakan metode yang paling sederhana dan paling sering digunakan untuk membuat piksel menjadi lebih besar. Kelebihan Interpolasi Nearest Neighbor adalah memanfaatkan teknik replikasi piksel. Interpolasi Bilinear menentukan nilai piksel baru baru dengan melakukan proses perataan sehingga menghasilkan sisi yang lebih halus dan sedikit jaggies (Hartanto, 
2015). Interpolasi Bicubic merupakan metode interpolasi yang lebih canggih dan hasilnya lebih halus dibandingkan dengan metode Interpolasi Bilinear.

Interpolasi matematika, banyak digunakan dalam proses geometris citra digital. Dalam proses geometris citra, piksel-piksel citra dipetakan dari satu citra ke citra lainnya melalui teknik pemetaan forward maupun teknik pemetaan reverse. Algoritma pengolahan citra yang menerapkan proses interpolasi antara lain adalah algoritma penskalaan (pembesaran atau digital zoom), rotasi citra serta proses-proses geometris dan kreatif lainnya.

Hasil interpolasi bisa sangat bervariasi bergantung pada algoritma interpolasi yang digunakan. Pada dasarnya interpolasi adalah proses pendekatan sehingga memungkinkan terjadi perubahan khususnya degradasi kualitas citra pada saat algoritma interpolasi diterapkan. Karena hal ini tak dapat dihindarkan, maka efek negatif proses interpolasi diusahakan seminimal mungkin dengan menerapakan algoritma interpolasi yang tepat dan sesuai dengan kebutuhan.

Penilaian kualitas citra yang dihasilkan dapat dilakukan dengan cara melakukan penilaian dengan memanfaatkan algoritma matematik berdasarkan suatu kriteria. Indeks kualitas yang sering digunakan adalah Mean Square Error (MSE) dan Peak Signal to Noise Ratio (PSNR).

\subsection{Metode Interpolasi Bicubic}

Interpolasi adalah suatu proses untuk menentukan nilai baru di suatu posisi yang terletak diantara beberapa sampel. Penentuan nilai baru tersebut dilakukan dengan suatu fungsi tertentu (Wulandari, 2017). Interpolasi citra digital bekerja secara dua arah. Proses ini berusaha untuk mendapatkan perkiraan nilai piksel warna dan intensitas yang terbaik berdasarkan nilai pada pikselpiksel di sekitarnya (Hadi, 2014)

Interpolasi memiliki jenis yang sering digunakan dalam penelitian meliputi: tetangga terdekat, bilinear, bicubic, spline, sinc, lanczos dan lain-lain. Semakin banyak piksel yang berdekatan maka akan lebih akurat, tapi ini memerlukan waktu pemrosesan yang lebih lama lagi. Algoritma ini dapat digunakan untuk mendistorsi dan merubah ukuran citra (Zolyviade, 2014) (Aisyah, 2011) (L. Brutman, 1997).

Berikut rumus untuk interpolasi :

$a=$ lokasi piksel tetangga terdekat

$$
f(x, y)=\sum_{i, j=0}^{N=1} a_{i, j} x^{i} y^{j}
$$

$x=$ lokasi piksel baru horisontal

$y=$ lokasi piksel baru vertikal

Interpolasi Bicubic adalah interpolasi dengan metode yang lebih canggih dan hasilnya lebih halus pada bagian tepitepinya daripada interpolasi bilinear. Interpolasi Bicubic menggunakan 4x4 piksel tetangga untuk mendapatkan informasi. Interpolasi Bicubic menghasilkan gambar yang terasa lebih tajam dibandingkan metode bilinear dan metode nearest neighbor (Wulandari, 2017). 


\begin{tabular}{|l|l|l|l|l|}
\hline$(\mathrm{i}-1, \mathrm{j}-1)$ & & & $(\mathrm{i}-1, \mathrm{j}+2)$ & \\
\hline & $(\mathrm{i}, \mathrm{j})$ & & & \\
\hline & & $(\mathrm{u}, \mathrm{v})$ & & \\
\hline & & & & \\
\hline$(\mathrm{i}+2, \mathrm{j}-1)$ & & & $(\mathrm{i}-2, \mathrm{j}+2)$ & \\
\hline
\end{tabular}

Gambar 1 Diagram Metode Interpolasi Bicubic (6)

\subsection{Dataset Super Resolusi}

Dataset sekunder "Set5" dan "Set14" (http://deeplearning.net/datasets/).

\begin{tabular}{|c|c|c|c|}
\hline Nama Image & Format & Ukuran Image & Image \\
\hline Baby & BMP & $504 \times 504$ \\
\hline Bird & BMP & $282 \times 282$ \\
\hline Butterfly & BMP & $249 \times 249$ \\
\hline Head & BMP & $273 \times 273$ \\
\hline Woman & BMP & $222 \times 336$ \\
\hline
\end{tabular}




\subsection{Mean Square Error (MSE)}

Mean Square Error merupakan suatu metode pengukuran kontrol dan kualitas yang sudah dapat diterima luas. MSE dihitung dari sebuah contoh objek yang kemudian dibandingkan dengan objek aslinya, sehingga dapat diketahui tingkat ketidak sesuaiannya antara objek contoh dengan aslinya (Hartanto, 2015).

$M S E=\frac{1}{m \times n} \sum_{i=0}^{n-1} \sum_{j=0}^{m-1}[X(i, j)-Y(i, j)]^{2}$

dimana :

$M, N:$ Lebar dan tinggi citra

$X(i, j)$ : Nilai intensitas citra asli pada posisi $x, y$

$Y(I, j):$ Nilai intensitas citra asli pada posisi $x, y$

\subsection{Peak Signal Noise Ratio (PSNR)}

Peak Signal Noise Ratio merupakan salah satu metode pengukuran yang digunakan untuk sistem rekonstruksi super resolusi gambar. Semakin besar PSNR, maka kualitas gambar semakin baik (Hartanto, 2015).

$P S N R=10 \log _{10}\left(\frac{255^{2}}{M S E}\right)$

\section{Tinjauan Pustaka}

\subsection{Citra Digital}

Citra biasanya digunakan dalam bidang pengolahan citra. Citra diartikan sebagai fungsi dua variabel $f(x, y), x$ dan $y$ adalah koordinat spasial dan nilai $f(x, y)$ adalah intensitas citra pada koordinat tersebut.

Citra digital dapat disajikan dalam bentuk matriks berdimensi $M x N$ dengan $M$ menyatakan baris dan $N$ menyatakan kolom. Masing-masing nilai pada matriks tersebut mewakili nilai derajat keabuan dari citra. Persamaan (2.1) merupakan representasi citra dalam bentuk matriks (Rafael C, 2001).

$$
f(x, y)=\left[\begin{array}{cccc}
f(0,0) & f(0,1) & \cdots & f(0, N-1) \\
f(1,0) & f(1,1) & \cdots & f(1, N-1) \\
\vdots & \vdots & \vdots & \vdots \\
f(M-1,0) & f(M-1,1) & \cdots & f(M-1, N-1)
\end{array}\right]
$$

Dimana, $f(x, y)$ menunjukkan nilai keabuan. Nilai pada baris dan kolom (pada posisi $x$ dan $y$ ) sering disebut dengan istilah piksel. Suatu piksel memiliki nilai dalam rentang tertentu, tergantung dari jenis warnanya. Namun secara umum jangkauannya adalah 0-255. Berikut adalah jenis-jenis citra berdasarkan nilai pikselnya:

\section{Citra Biner}


Citra biner adalah citra digital yang hanya memiliki dua kemungkinan nilai piksel yaitu hitam dan putih. Citra biner sering muncul sebagai hasil dari proses pengolahan citra seperti segmentasi, pengambangan, ataupun morfologi.

\section{Citra Greyscale}

Citra grayscale merupakan citra digital yang hanya memiliki satu nilai kanal pada setiap pikselnya, dengan kata lain nilai RED $=$ GREEN $=$ BLUE. Nilai tersebut digunakan untuk menunjukkan tingkat intensitas. Citra ini memiliki kedalaman warna 8 bit (256 kombinasi warna keabuan). Pengubahan dari citra berwarna ke bentuk greyscale mengikuti aturan yang disajikan pada Persamaan (2.2) (Darma, 2010).

$$
s=\frac{r+g+b}{3}
$$

dengan :

$s=$ Nilai intensitas citra greyscale

$r$ = Nilai intensitas warna merah dari citra asal

$g=$ Nilai intensitas warna hijau dari citra asal

$b=$ Nilai intensitas warna biru dari citra asal

3. Citra Warna

Citra warna ada 3 macam yaitu 8 bit, 16 bit, 24 bit. Perbedaannya hanya terletak pada jumlah variasi warna, 8 bit memiliki 256 variasi warna, 16 bit memiliki 65.536 variasi warna, sedangkan 24 bit memiliki 16.777.216 variasi warna.

\subsection{Super Resolusi}

Resolusi citra menggambarkan detil dari sebuah citra, semakin tinggi resolusi citra maka semakin tinggi ketajamannya. Dalam istilah citra digital resolusi citra sering dinyatakan dengan banyaknya piksel dari suatu citra, misalkan: citra dengan ukuran 256x256 mempresentasikan 256 pixel pada kolomnya dan 256 pixel pada barisnya (Ivado, 2014).

Resolusi citra adalah suatu ukuran kualitas dari keluaran sebuah citra yang biasa dikaitkan dengan piksel. Resolusi citra menggambarkan detil dari sebuah citra, semakin tinggi resolusi citra maka semakin tinggi ketajamannya. Dalam istilah citra digital resolusi citra sering dinyatakan dengan banyaknya piksel dari suatu citra, misalkan: citra dengan ukuran 256 × 256 mempresentasikan 256 pixel pada kolomnya dan 256 pixel pada barisnya (Remimol, 2014).

Prinsip resolusi citra adalah meningkatkan jumlah piksel gambar, dimana gambar dengan resolusi yang rendah diubah menjadi gambar dengan resolusi tinggi (D. Han, 2013). Contoh, ketika sebuah citra berukuran kecil diperbesar $400 \%$. Citra tersebut mempunyai empat buah nilai piksel intensitas citra yang ditandai sebagai A, B, C, dan D pada Gambar 2 (a). Pada saat proses perbesaran ukuran citra nilai intensitas A, B, C, dan D ini direnggangkan, sehingga terdapat beberapa nilai intensitas piksel baru di antara nilai intensitas piksel yang sudah ada, contohnya piksel P. penentuan nilai-nilai intensitas piksel baru $\mathrm{P}$, dapat dilakukan dengan suatu perhitungan perkiraan interpolasi pada Gambar 1 (b). (D. Han, 2013)

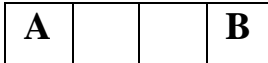




\begin{tabular}{|l|l|l|l|}
\hline $\mathbf{A}$ & $\mathbf{B}$ & & \\
\hline $\mathbf{C}$ & $\mathbf{D}$ & & \\
\hline & & & \\
\hline & & & \\
\hline
\end{tabular}

a.

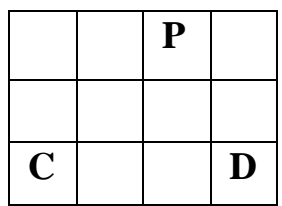

b.

Gambar 1 Skema Resolusi Citra

\section{Metode Penelitian}

\subsection{Pengambilan Data}

Dalam penelitian ini menggunakan data berupa citra RGB dengan berbagai berbagai ukuran yang berbeda-beda dan format citra image BMP. Penelitian ini menggunakan dataset sekunder "Set5" dan "Set14" (http://deeplearning.net/datasets/). Table 4.1 menunjukkan beberapa contoh dari dataset.

Table 3.1 contoh dataset super resolusi

\begin{tabular}{|l|l|l|l|}
\hline Nama Image & Format & Ukuran Image & Image \\
\hline Baby (Set5) & BMP & $504 \times 504$ & \\
\hline Bird (Set5) & BMP & $282 \times 282$ & \\
\hline Zebra (Set14) & BMP & $579 \times 384$ & \\
\hline Baboon (Set14) & BMP & $492 \times 474$ & \\
\hline Flower (Set14) & BMP & $492 \times 354$ & \\
\hline
\end{tabular}




\subsection{Giagram Alir}

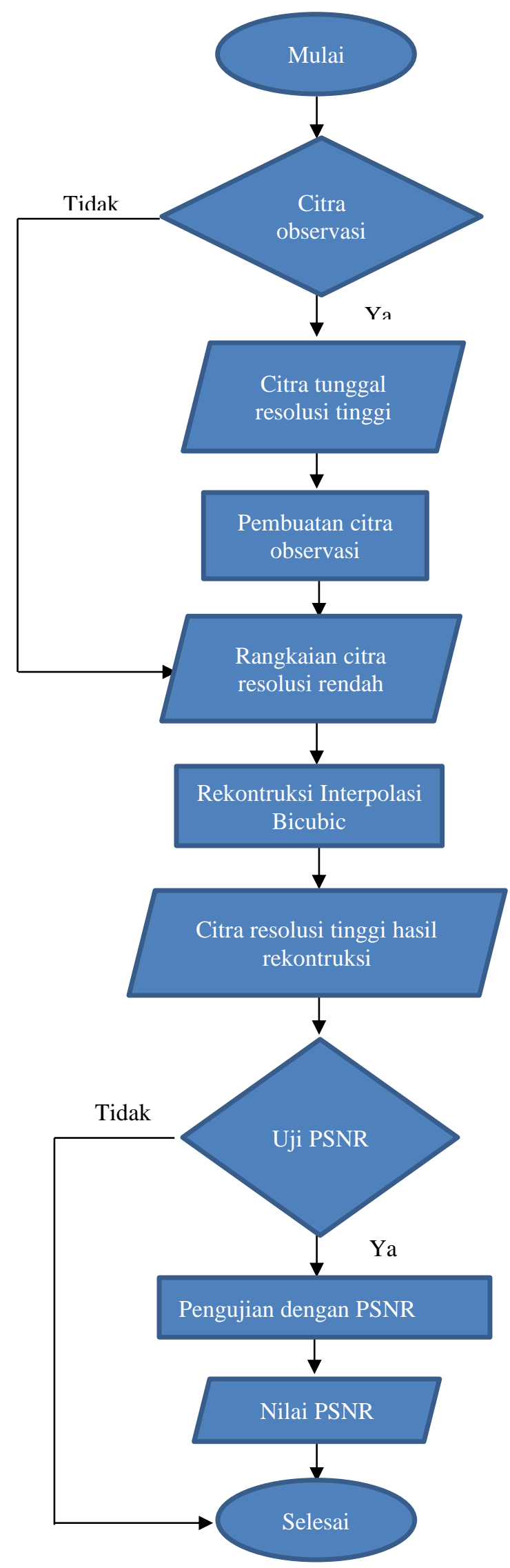




\section{Hasil dan Pembahasan}

\subsection{Downsampling}

Pada tahap selanjutnya adalah melakukan downsampling pada citra. Downsampling dilakukan pada semua citra untuk menghasilkan ukuran citra yang lebih kecil dan mengurangi kualitas citra dengan metode polynomial lagrange. Proses downsampling digunakan untuk memperkecil resolusi dari sebuah citra dengan menghilangkan sebagian piksel, hal itu berpengaruh pada kualitas citra yang dihasilkan. Untuk menjaga kualitas citra, maka metode interpolasi Bicubic modifikasi digunakan dalam proses downsampling. Interpolasi bicubic merupakan modifikasi dari interpolasi bicubic dengan kualitas yang sama dan waktu pemrosesan yang lebih cepat. Maka pada penelitian ini akan dibahas mengenai implementasi metode interpolasi bicubic modifikasi pada proses downsampling citra yang dilakukan dengan menghitung 16 piksel terdekat yang terdapat pada citra input dan dihasilkan nilai piksel baru. Pengujian dilakukan pada citra yaitu RGB. Hasil pengujian menunjukkan bahwa ukuran file citra output pada citra RGB (Jagadeesan, 2014) (M Rinaldi, 2010) (Jagadeesan, 2014).

$$
f(x, y)=\sum_{i=0}^{3} \sum_{j=0}^{3} a_{i j} I_{i j}
$$

yang meruapakan hasil perkalian matriks citra $I$ dan variabel $a_{i j}$ yang didapat dari polinomial Lagrange.

\subsection{Algoritma Interpolasi Bicubic}

Sebuah piksel merupakan fungsi bicubic menggunakan 16 piksel pada $4 \times 4$ ketetanggaan dari citra asli. Algoritmanya adalah sebagai berikut:

1. Perbesar lebar dan tinggi sebanyak $3 x$ dan $4 x$

2. Lakukan interpolasi polinomial kubik secara vertikal dengan cara sebagai berikut:

(a) susun matriks augmented $y$

(b) lakukan metode eliminasi Gauss Jordan hingga diperoleh projection $p=a_{0}+a_{1} y+a_{2} y^{2}+a_{3} y^{3}$

(c) masukkan nilai $y$ dari piksel yang akan dicari ke persamaan di atas

3. Lakukan interpolasi polinomial kubik secara horizontal dengan cara sebagai berikut:

(a) susun matriks augmented $x$

(b) lakukan metode eliminasi Gauss Jordan hingga diperoleh

$$
\text { projection } p=a_{0}+a_{1} x+a_{2} x^{2}+a_{3} x^{3}
$$

(c) masukkan nilai $x$ dari piksel yang akan dicari ke persamaan di atas

4. lakukan pembulatan pada tiap piksel

Adapun matriks augmented $y$ dan $x$ adalah

$$
\begin{array}{llllllllllll}
1 & y_{1} & y_{1}^{2} & y_{1}^{3}= & p_{1} & 1 & x_{1} & x_{1}^{2} & x_{1}^{3} & = & p_{1} \\
1 & y_{2} & y_{2}^{2} & y_{2}^{3}= & p_{2} & 1 & x_{2} & x_{2}^{2} & x_{2}^{3}=p_{2} \\
1 & y_{3} & y_{3}^{2} & y_{3}^{3}= & p_{3} & 1 & x_{3} & x_{3}^{2} & x_{3}^{3}=p_{3} \\
1 & y_{4} & y_{4}^{2} & y_{4}^{3}= & p_{4} & 1 & x_{4} & x_{4}^{2} & x_{4}^{3}=p_{4}
\end{array}
$$


Tampilan sistem hasil implementasi metode interpolasi Bicubic pada proses ini dapat dilihat pada table hasil di bawah ini. Pengujian program dilakukan dua perbandingan yaitu pada upscale $3 \mathrm{x}$ dan upscale $4 \mathrm{x}$, untuk mengimplementasikan interpolasi bicubic menggunakan 19 citra image RGB dengan format BMP. Pengujian dinilai berdasarkan ukuran file citra, nilai PSNR untuk menilai kualitas citra hasil super resolusi dan hasil nilai PSNR di rata-rata berdasarkan kumpulan dataset "Set5" dan "Set14".

Tabel 4.1 Hasil Interpolasi Bicubic upscale 3x

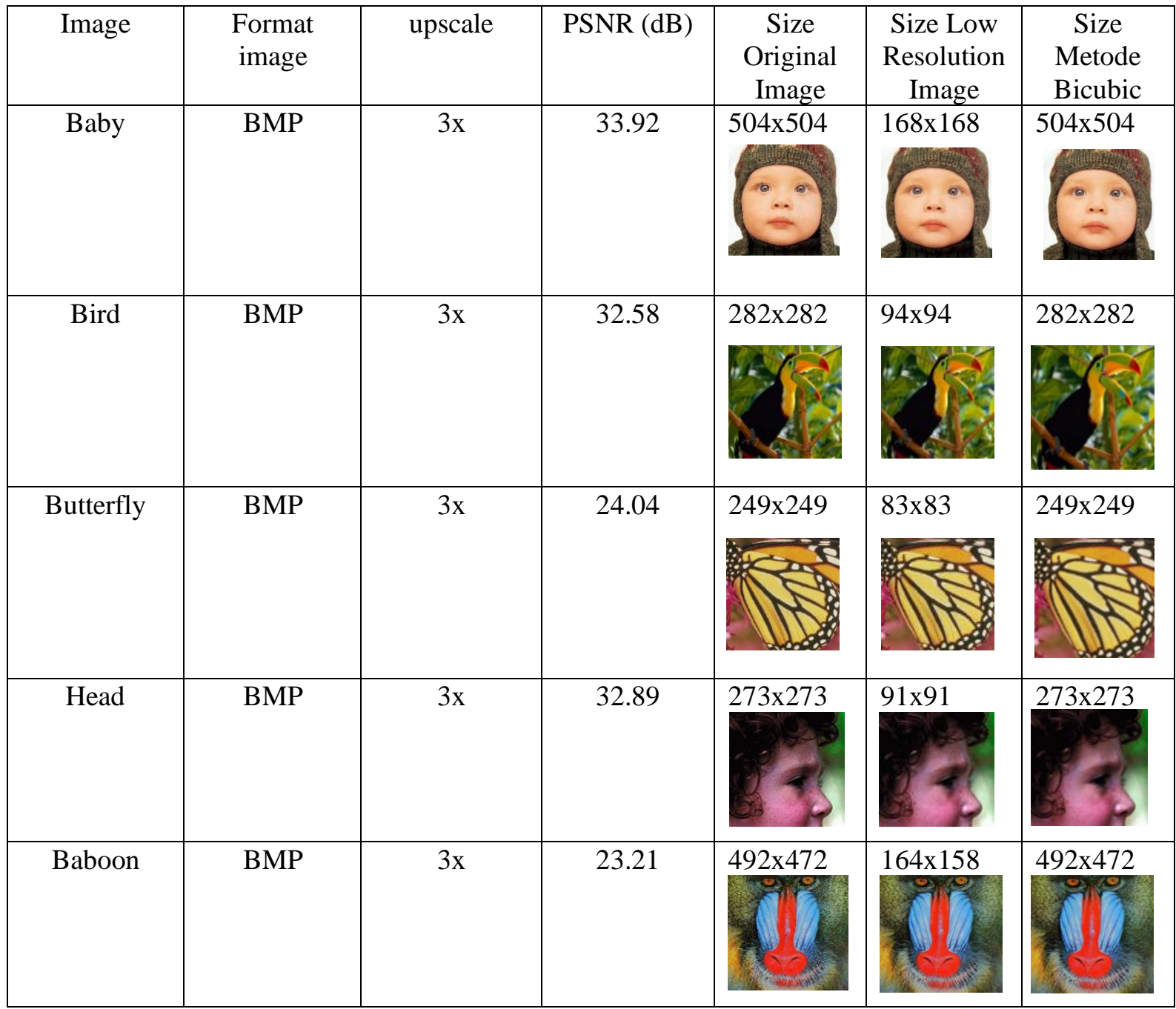


Tabel 4.2 Hasil Interpolasi Bicubic upscale 4x

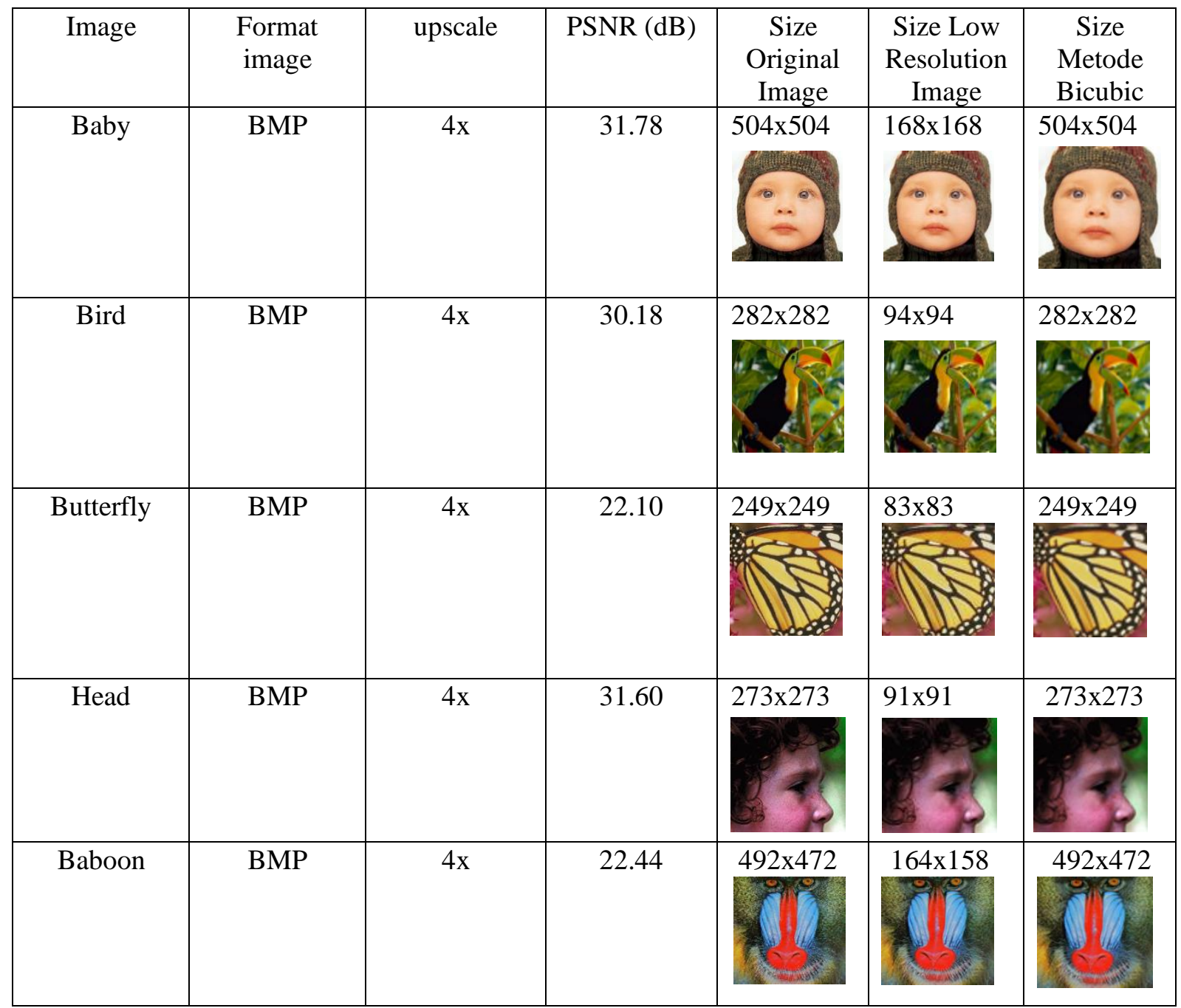

HR Image

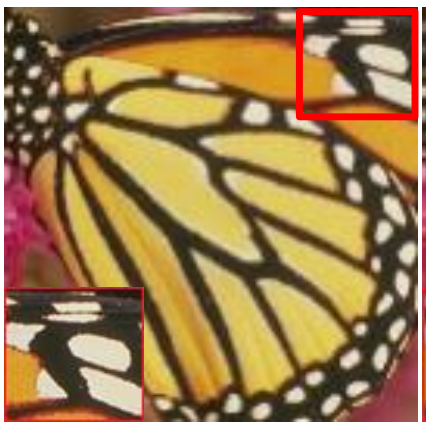

HR Image
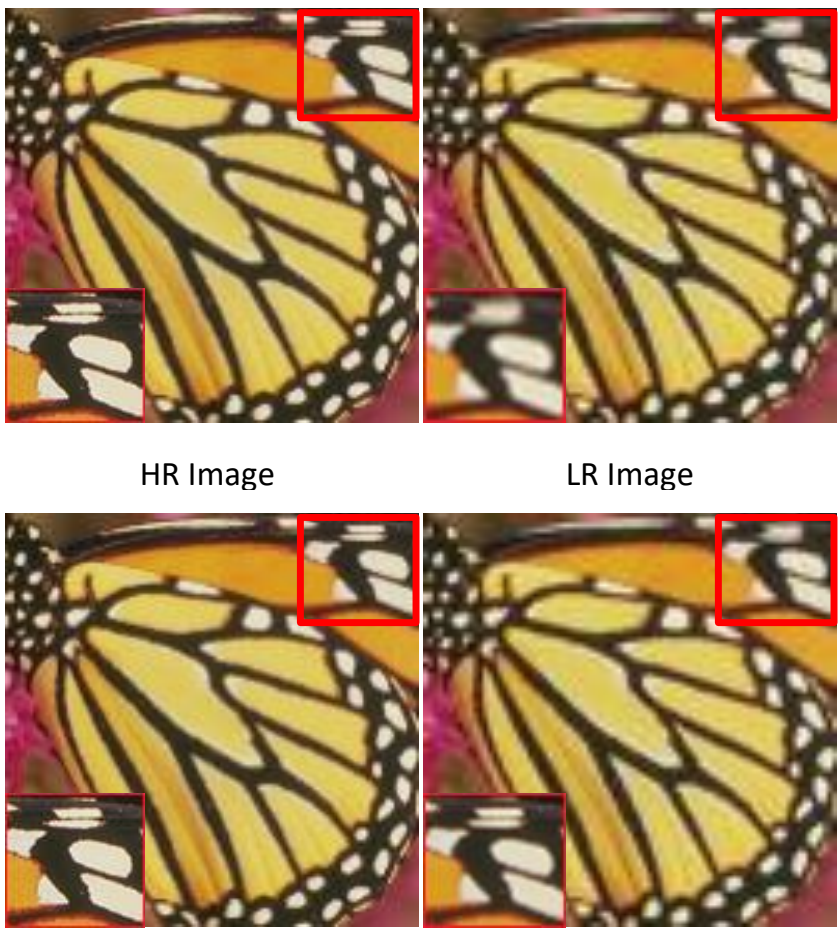

LR Image
Metode Bicubic 3x

Metode Bicubic $4 x$

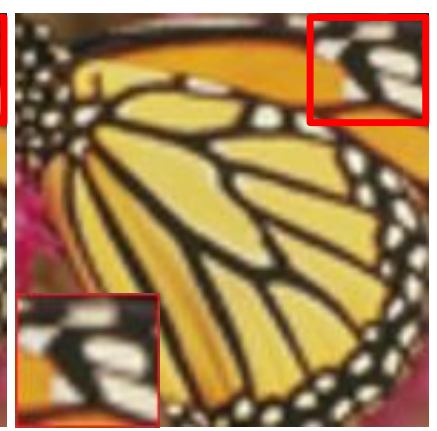


Proses pengujian dinilai dari ukuran file citra output, waktu pemrosesan dan kualitas citra. Untuk mengukur kualitas citra digunakan Peak Signal to Noise Ratio (PSNR). PSNR merupakan rasio antara nilai maksimum sebuah sinyal dan nilai noise yang berpengaruh pada sinyal tersebut (Wayan, 2011). Semakin besar nilai PSNR maka akan semakin tinggi kualitas dari citra output.

\begin{tabular}{|l|l|l|}
\hline \multirow{2}{*}{ images } & Bicubic & Bicubic \\
\cline { 2 - 3 } & PSNR & PSNR \\
\cline { 2 - 3 } & $\mathbf{3 x}$ & $\mathbf{4 x}$ \\
\hline Baby & 33.92 & 31.78 \\
\hline Bird & 32.58 & 30.18 \\
\hline Butterfly & 24.04 & 22.10 \\
\hline Head & 32.89 & 31.60 \\
\hline Woman & 33.92 & 26.46 \\
\hline Average & $\mathbf{3 0 . 4 0}$ & $\mathbf{2 8 . 4 3}$ \\
\hline Baboon & 23.21 & 22.44 \\
\hline Barbara & 26.25 & 25.15 \\
\hline Bridge & 24.40 & 23.15 \\
\hline Coastguard & 26.55 & 25.48 \\
\hline Comic & 23.12 & 21.69 \\
\hline Face & 32.83 & 31.56 \\
\hline Flowers & 27.23 & 25.53 \\
\hline Foreman & 31.16 & 29.39 \\
\hline Lenna & 31.69 & 29.84 \\
\hline Man & 27.01 & 25.70 \\
\hline Monarch & 29.43 & 27.46 \\
\hline Pepper & 32.39 & 30.60 \\
\hline PPT3 & 23.71 & 21.97 \\
\hline Zebra & 26.64 & 24.08 \\
\hline Average & $\mathbf{2 7 . 5 4}$ & $\mathbf{2 6 . 0 0}$ \\
\hline & & \\
\hline
\end{tabular}

\section{5.kesimpulan}

Berdasarkan hasil pengujian dan analisis, dapat diambil kesimpulan sebagai berikut

1. Nilai PSNR tertinggi pada citra jenis RGB dihasilkan oleh citra dengan format BMP, jika ukurannya citra image semakin besar maka semakin besar pula nilai PSNR nya dan nilai tertinggi rata-rata dari nilai PSNR adalah pada upscale 3x.

2. Untuk kualitas citra image RGB menggunakan 16 piksel pada $4 \times 4$ ketetanggaan dari citra asli dan dihasilkan nilai piksel baru sehingga nilai piksel pada citra output akan serupa dengan nilai piksel pada citra input. 


\section{Referensi}

Yudhi Purwananto, S.Kom, M.Kom, Rully Soelaiman, S.Kom, M.Kom Lulu Ardiansyah, "Rekonstruksi Citra Super-Resolusi Menggunakan Kerangka Kerja Soft," 2010.

Imaddudin Septyan P, "REKONSTRUKSI CITRA MENGGUNAKAN ALGORITMA STRUCTUREADAPTIVE NORMALIZED CONVOLUTION," 2011.

ST Ni Wayan Sumartini Saraswati, "TRANSFORMASI WAVELET DAN THRESHOLDING PADA CITRA MENGGUNAKAN MATLAB," 2011.

B. Hartanto. "Analisa Bicubic Dan Bilinear Menggunakan Metode Discrete Wavelet Transform Pada Super Resolusi”. Tugas Akhir, Fakultas Ilmu Komputer Universitas Dian Nuswantoro Semarang. 2015

M. Wulandari. "Index Quality Assesment Citra Terinterpolasi (SSIM dan FSIM)". Jurnal Terapan Teknologi Informasi (JUTEI). vol. 1, no. 1, April 2017. pp. 11-20.

D. Han, "Comparison of Commonly Used Image Interpolation methods". Proceedings of the $2^{\text {nd }}$ International Conference on Computer Science and Electronics Engineering (ICCSEE). 2013. pp. 1556-1559.

Zolyviade Zarcelonia, "Perancangan Aplikasi Perbesaran Citra dengan Metode Proyeksi Cahaya," 2014.

Siti Aisyah dan Fitri Arnia Nailul Mustaqim Abdi, "Peningkatan Kualitas Citra Digital Menggunakan Metode Super Resolusi Pada Domain Spasial," 2011.

S. Hadi. "Metode Interpolasi Dan Implementasinya Dalam Citra Digital”. 2014.

Rafael C. Gonzalez, Richard E. Woods Digital Image Processing 2nd Addison-Wesley Longman Publishing Co., Inc. Boston, MA, USA (02001 ISBN:0201180758

Ivando, 2014, Implementasi Metode Interpolasi Bicubic Modifikasi untuk Perbaikan Citra Hasil Penskalaan, STMIK GI MDP, Palembang.

Munir, Rinaldi 2010, Metode Numerik, Informatika, Bandung

Jagadeesan, N. dan Parvathi, R.M.S 2014, An Efficient Image Downsampling Technique Using Genetic Algorithm and DWT, Journal of Theoretical and Applied Information Technology.

Remimol 2014, A Method of DWT With Bicubic Interpolation for Image Scaling, International Journal of Computer Science Engineering (IJCSE), Vol. 3, No. 02.

L. Brutman (1997), Lebesgue functions for polynomial interpolation a survey, Ann. Numer. Math. 4, 111127

Jagadeesan, N. dan Parvathi, R.M.S 2014, An Efficient Image Downsampling Technique Using Genetic Algorithm and DWT, Journal of Theoretical and Applied Information Technology 